\title{
Development of a filtration system with high-frequency flow reversal
}

\author{
Marinaldo F. Pinto ${ }^{1}$, Dinara G. Alves ${ }^{1}$, Ezequiel Saretta ${ }^{2}$, Antonio P. de Camargo ${ }^{2} \&$ Tarlei A. Botrel $^{2}$ \\ ${ }^{1}$ Universidade Federal do Rio de Janeiro/Instituto de Tecnologia/Departamento de Engenharia. Seropédica, RJ. E-mail: marinaldo@ufrrj.br (Corresponding \\ author); dinara_alves@hotmail.com \\ ${ }^{2}$ Universidade de São Paulo/Escola Superior de Agricultura "Luiz de Queiroz"/Departamento de Engenharia de Biossistemas, Piracicaba, SP. E-mail: \\ saretta@usp.br; apcpires@usp.br; tabotrel@usp.br
}

\section{Key words:}

water quality

emitter clogging

screen filter

\begin{abstract}
A B S T R A C T
The aim of this study was to develop a filtration system with high-frequency flow reversal and minimum requirement of water for cleaning routines. The system was developed in the period from 2011 to 2013 and consists of three screen filters and eleven solenoid valves electronically controlled by a controller that operates based on head loss measurements. The following evaluations were carried out: head loss curve as a function of flow rate; filtrating efficiency as a function of solids concentration, frequency of flow reversal and increment in head loss. The experimental design was completely randomized in a factorial scheme with three replicates and two treatment levels for each factor. The filtration efficiency was equal to $98.6 \%$ for particles larger than $50 \mu \mathrm{m}$. The minimum volume of water for each cleaning of the filters was $5.39 \mathrm{~L}$. The head loss increment in the filtration system with flow reversal at frequencies of 11.11 and $22.22 \mathrm{mHz}$ was smaller compared with the filtration system without flow reversal. The developed filtration system has potential for filtering low-quality irrigation water, but requires periodic maintenance to clean the filter element.
\end{abstract}

Palavras-chave: qualidade da água obstrução de emissores filtro de tela

\section{Desenvolvimento de um sistema de filtragem com reversão de fluxo de alta frequência}

\section{R E S U M O}

Este trabalho objetivou desenvolver um sistema de filtragem com inversão automática de fluxo de alta frequência e consumo mínimo de água de limpeza. O sistema foi desenvolvido no período de 2011 a 2013 e é composto de três filtros de tela e onze válvulas solenoides, acionadas eletronicamente por controlador baseado na perda de carga. Avaliou-se a curva de perda de carga em função da vazão e a eficiência de filtragem em função da concentração de sólidos, frequência de inversão de fluxo e incremento da perda de carga. O delineamento experimental foi inteiramente aleatorizado em esquema fatorial com três repetições e dois níveis de tratamento para cada fator. A eficiência de filtragem para sólidos maiores que 50 $\mu \mathrm{m}$ foi de $98,6 \%$. O volume mínimo de água para cada limpeza dos filtros foi de 5,39 L. A inversão de fluxo com frequências de 11,11 e 22,22 $\mathrm{mHz}$ reduziu a taxa de crescimento da perda de carga comparado ao sistema funcionando sem inversão de fluxo. O sistema de filtragem apresentou potencial para filtragem da água de baixa qualidade para irrigação porém necessita de manutenções periódicas para limpeza do elemento filtrante. 


\section{INTRODUCTION}

Emitter clogging may compromise the application uniformity of micro-irrigation systems due to the uneven reduction in the flow rate of the emitters; in addition, a reduction in the applied water depth may occur (Batista et al., 2010; Ribeiro et al., 2008). Increase in emitter clogging of approximately 1 to $5 \%$ may result in great loss of application uniformity (Nakayama \& Books, 1981). According to Frizzone et al. (2012), the total clogging of 5 to $10 \%$ of the emitters promotes coefficients of variation in the flow rate from 23 to $33 \%$. Additionally, according to Camargo et al. (2013), the effect of emitter clogging on the hydraulic variables of the lateral line depends on the location of the clogged emitters.

Although the causing agents of emitter clogging have different natures, i.e., physical, chemical or biological, Adin \& Alon (1986) observed that most of the causes of clogging are due to the presence of materials in suspension, showing the importance of a filtration system for micro-irrigation. It should be pointed out that the prevention of emitter clogging should not be based only on agents of physical nature, but also on the other agents, in combination, because in many cases they occur simultaneously (Lemos Filho et al., 2011; Pinto et al., 2011).

Thus, various studies have shown that filtration systems can be more or less efficient due to the different natures of the causing agents of clogging. According to Testezlaf (2008), sand filters are recommended for the removal of organic contaminants and algae, while screen or disc filters should be used to retain solid particles of physical nature, which is the reason why they are commonly used after the sand filter, in order to retain particles from fertilizer injection systems (Frizzone et al., 2012).

Many studies have confirmed that screen or disc filters are efficient at retaining small-diameter solid particles; however, when subjected to water of low quality, with large amount of impurities, such as algae and organic matter, they are very susceptible to clogging and require frequent cleanings (Adin \& Elimelech, 1989; Tajrishy et al., 1994; Puig-Bargués et al., 2005; Duran-Ros et al. 2009a). All of these authors evaluated the screen filter subjected to wastewater and observed that its clogging occurred rapidly, and Tajrishy et al. (1994) reported the necessity of daily cleanings considering a head loss limit of $55 \mathrm{kPa}$. Puig-Bargués et al. (2005) and Duran-Ros et al. (2009a) observed that, when screen or disc filters are clogged, particles may detach due to the increase in pressure, reducing the efficiency or even increasing the concentration of solids in suspension. However, the results found by these authors were obtained with filters working in the traditional way, i.e., without flow reversal. According to Testezlaf \& Ramos (1995), screen filters must be cleaned immediately after use, in order to prevent particles from becoming strongly aggregated, which makes their removal difficult. High-frequency flow reversal may promote the removal of these particles.

Given the above, this study aimed to develop an automatic filtration system with high-frequency flow reversal, high efficiency and low water requirement for cleaning.

\section{Material AND Methods}

\section{Description and characterization of the filtration system}

The filtration system was developed from 2011 to 2013 and consists of three filters (model: Amiad 1" Super with filter element of $130-\mu \mathrm{m}$ screen and nominal flow rate of $\left.7 \mathrm{~m}^{3} \mathrm{~h}^{-1}\right)$ and eleven electronically controlled solenoid valves (model: Bermad 220-M DN-25, with flow rate of $5.5 \mathrm{~m}^{3} \mathrm{~h}^{-1}$ for a head loss of $30 \mathrm{kPa}$ ).

The prototype assembly scheme is shown in Figure 1A, where the components F1, F2 and F3 represent filters, V1 to V8 the flow-direction control valves and VL1, VL2 and VL3 represent valves for the cleaning of the filters.

The components were interconnected using fittings and pipes. The configuration, composed of three filters, aimed to condition the flow reversal in the filters with the system in operation, by activating the sequence of valves as shown in Table 1. Each sequence of opening of the valves promotes a pathway for the water in the filtration system, as described by Pinto (2013).

The head loss curve as a function of flow rate was determined and the tests were performed using clean water for the three operation conditions of the system (F1, F2 and

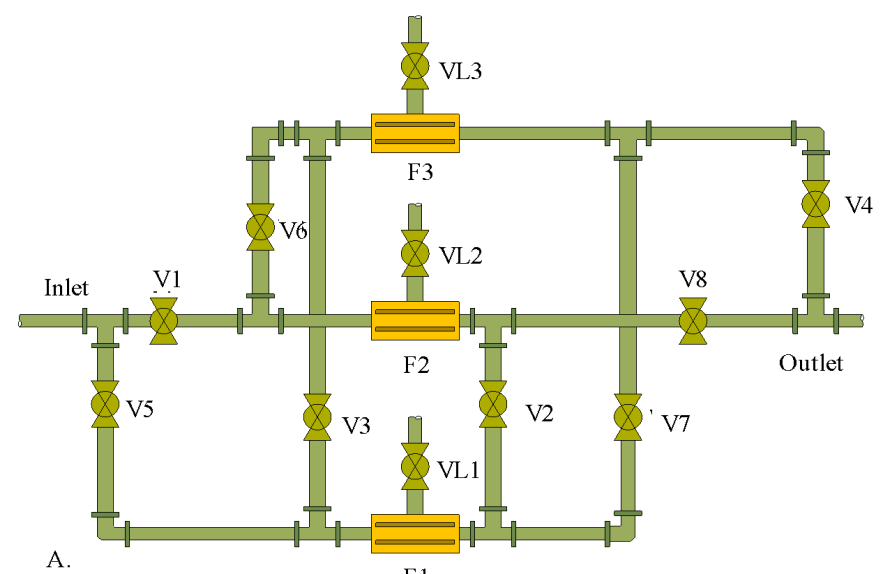

$\mathrm{F} 1$

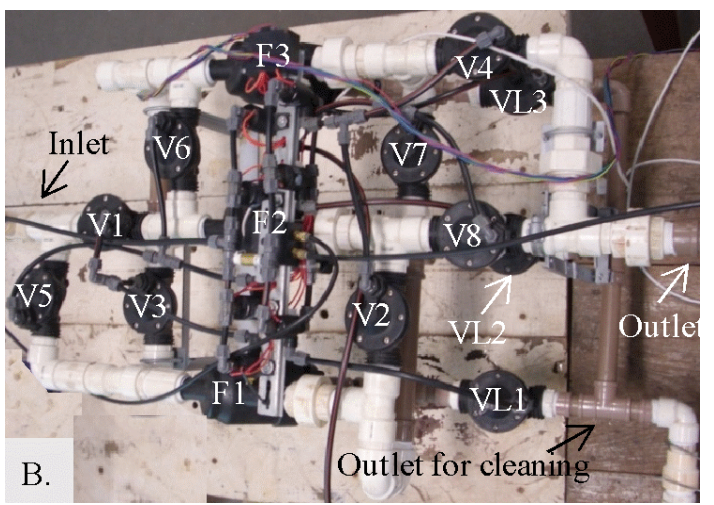

$F 1, F 2$ and $F 3$ - Filters; $V 1$ to V8 - Flow control valves; and VL1, VL2 and VL3 - Fiter cleaning valves Figure 1. Assembly scheme of the filtration system (A) and the prototype (B)

Table 1. Sequence of opening of the valves as a function of the filter in reversal and/or under cleaning

\begin{tabular}{cccccc}
\hline $\begin{array}{c}\text { Filter in reversal } \\
\text { and/or under cleaning }\end{array}$ & \multicolumn{5}{c}{ Open valves } \\
F1 & V1 & V2 & V3 & V4 & VL1 \\
F2 & V5 & V2 & V6 & V4 & VL2 \\
F3 & V5 & V7 & V6 & V8 & VL3 \\
\hline F1 F2 and F3 - Filers
\end{tabular}

F1, F2 and F3 - Filters; V1 to V8 - Flow control valves; VL1, VL2 and VL3 - Filter cleaning valves 
F3 in reversal, individually). Eleven flow rate points were tested, varying from 0.5 to $5.5 \mathrm{~m}^{3} \mathrm{~h}^{-1}$ with increments of 0.5 $\mathrm{m}^{3} \mathrm{~h}^{-1}$. This number of points is higher than the seven points recommended by the norm ASAE S 539 (ASABE, 2008). Head loss was determined using a differential mercury manometer installed between the inlet and the outlet of the filtration system. Flow rate was determined using an electromagnetic meter installed before the filtration system and controlled using a valve installed after the meter. The pressure in the inlet of the system was maintained at $196.2 \mathrm{kPa}$ and the head loss curve as a function of the flow rate was adjusted to a potential model.

\section{Minimization of cleaning water volume}

The water volume required for the cleaning of each filter depends on the water pressure inside the filter and on the time of opening of its cleaning valve. In order to minimize this water volume, different combinations of opening times of cleaning valves were analysed, according to Table 2 . The opening time of each valve ranged from 0.25 to $2.0 \mathrm{~s}$ and the opening was performed using electrical pulses. Three consecutive electrical pulses, spaced by $1 \mathrm{~s}$, were adopted; therefore, the total opening time of the valve in each filter cleaning ranged from 1 to $3 \mathrm{~s}$.

Cleanings were performed when the head loss increment reached $50 \%$. For each combination of time, the cleaning water was collected for volume determination. Time combinations that were not tested were due to ineffective cleaning.

Table 2. Combinations of pulse times to open the cleaning valves of the filters F1, F2 and F3, used in the tests of the system

\begin{tabular}{|c|c|c|c|c|c|c|}
\hline \multicolumn{4}{|c|}{ Pulse times (ms) } & \multirow{2}{*}{ F1 } & \multirow{2}{*}{ F2 } & \multirow{2}{*}{ F3 } \\
\hline 1 & 2 & 3 & Total & & & \\
\hline \multirow{3}{*}{-} & 1000 & \multirow{3}{*}{500} & 1500 & $\checkmark$ & $\checkmark$ & - \\
\hline & 1500 & & 2000 & $\checkmark$ & $\checkmark$ & - \\
\hline & 2000 & & 2500 & $\checkmark$ & $\checkmark$ & $\checkmark$ \\
\hline \multirow{4}{*}{250} & 500 & \multirow{4}{*}{250} & 1000 & $\checkmark$ & $\checkmark$ & $\checkmark$ \\
\hline & 750 & & 1250 & $\checkmark$ & $\checkmark$ & $\checkmark$ \\
\hline & 1000 & & 1500 & $\checkmark$ & $\checkmark$ & - \\
\hline & 1500 & & 2000 & $\checkmark$ & $\checkmark$ & $\checkmark$ \\
\hline \multirow{3}{*}{500} & 1000 & \multirow{3}{*}{500} & 2000 & - & - & $\checkmark$ \\
\hline & 1500 & & 2500 & $\checkmark$ & - & $\checkmark$ \\
\hline & 2000 & & 3000 & - & - & $\checkmark$ \\
\hline
\end{tabular}

$\checkmark$ Test performed; - Test not performed

\section{Evaluation of the filtration system's retention efficiency}

Filtration efficiency was measured in tests performed in completely randomized design, in $2 \times 2 \times 2$ factorial scheme, with three replicates. The following factors were considered: concentration of solids larger than $50 \mu \mathrm{m}\left(500\right.$ and $\left.1000 \mathrm{mg} \mathrm{L}^{-1}\right)$; flow reversal frequency $(11.11$ and $22.22 \mathrm{mHz})$ and head loss increment for filter cleaning (25 and 50\%).

The composition of the concentration of solids was obtained through the injection of solids directly into the inlet pipe of the filtration system, using the arrangement of valves installed in the piping, as shown in Figure 2. Particle injection rates were 33.3 and $16.7 \mathrm{~g} \mathrm{~min}^{-1}$ for the concentrations of 1000 and $500 \mathrm{mg} \mathrm{L}^{-1}$, respectively, since the flow rate of the filtration system was $2 \mathrm{~m}^{3} \mathrm{~h}^{-1}$.

Retention efficiency was obtained based on the total mass of solids in the inlet and the total mass of solids retained by the filters (Eq. 1). In addition, the efficiency of retention of solids

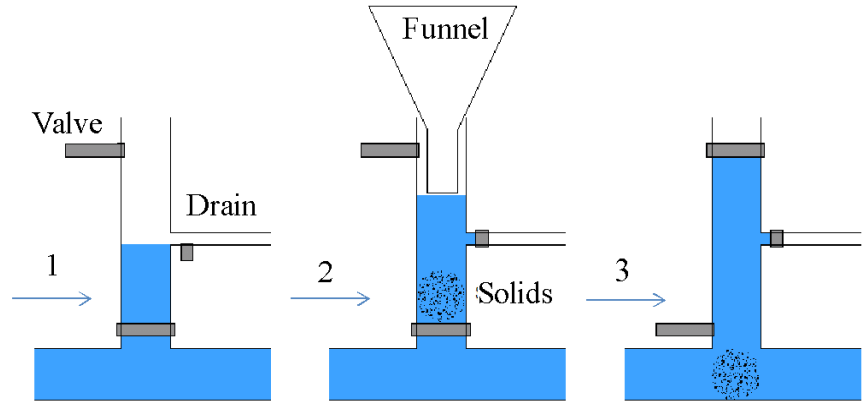

Figure 2. Scheme of the solids injection system

larger than $50 \mu \mathrm{m}$ was determined, i.e., referring to particles injected into the pipes (Eq. 2). For each treatment level, samples of the water used in the tests and cleaning water were collected and the total mass of solids used in the tests was obtained by drying the samples in an oven.

The filtered volume was measured using a water meter with flow rate range from 0 to $2.5 \mathrm{~m}^{3} \mathrm{~h}^{-1}$ and the volume of cleaning water was determined through weighing, as in the tests of minimum volume.

$$
\begin{gathered}
\mathrm{Er}=\frac{\mathrm{m}_{\mathrm{r}}+\mathrm{C}_{1} \mathrm{~V}_{1}}{\mathrm{~m}_{\mathrm{t}}+\mathrm{C}_{\mathrm{e}}\left(\mathrm{V}+\mathrm{V}_{1}\right)} \times 100 \\
\mathrm{E}_{\mathrm{d}>50}=\frac{\mathrm{m}_{\mathrm{r}}}{\mathrm{m}_{\mathrm{t}}} \times 100
\end{gathered}
$$

where:

Er - filtration efficiency, \%;

$\mathrm{E}_{\mathrm{d}>50}$ - filtration efficiency for solids with diameter larger than $50 \mu \mathrm{m}, \%$;

$\mathrm{m}_{\mathrm{r}}$ - mass of solids with diameter larger than $50 \mu \mathrm{m}$, retained by the filters, $\mathrm{g}$;

$m_{t} \quad$ - mass of solids injected into the filters, $g$;

$\mathrm{C}_{1}$ - concentration of solids with diameter smaller than $50 \mu \mathrm{m}$, present in the cleaning water, $\mathrm{g} \mathrm{L}^{-1}$;

$\mathrm{C}_{e}$ - concentration of solids with diameter larger than $50 \mu \mathrm{m}$ injected in the inlet of the system, $\mathrm{g} \mathrm{L}^{-1}$;

$\mathrm{V}$ - filtered volume, $\mathrm{L}$; and,

$\mathrm{V}_{1} \quad$ - volume of cleaning water, $\mathrm{L}$.

For the separation of particles with diameters larger and smaller than $50 \mu \mathrm{m}$, a sieve $\left(\mathrm{ABNT} \mathrm{n}^{\circ} 270,53 \mu \mathrm{m}\right)$ was connected to the inlet of the container for the collection of cleaning water, where the solids of the sand fraction were retained.

\section{Results AND Discussion}

\section{Curve of flow rate $\mathrm{x}$ head loss in clean water}

The characteristic head loss curve as a function of the inlet flow rate of the filtration system, with screen filter, for the three operating conditions, i.e., with one of the filters in reversal, is shown in Figure 3. The curve showed a potential behavior, as suggested by Testezlaf \& Ramos (1995) and Oliveira et al. (2007). Even considering the three flow directions, the potential model adjusted well to the data and showed a coefficient of determination of 0.9986 . 


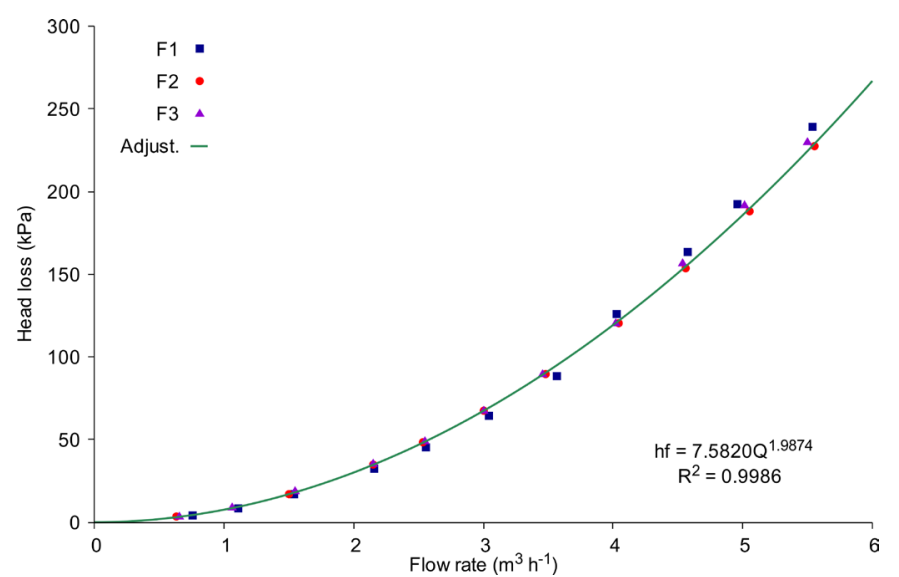

Adjust: adjusted curve; F1, F2 and F3: filter 1, 2 and 3 in reversal, respectively

Figure 3. Characteristic curve of head loss as a function of the inlet flow rate of the filtration system

For the flow rate of $5 \mathrm{~m}^{3} \mathrm{~h}^{-1}$, the head loss in the filtration system was approximately $196.2 \mathrm{kPa}$ and, for the three filters in series, it would be approximately $60 \mathrm{kPa}$, because the value for each filter was $20 \mathrm{kPa}$, evidencing that other components of the system contributed to the head loss, especially the control valves. Each valve showed head loss of $24 \mathrm{kPa}$, in a total of 96 $\mathrm{kPa}$ for the four valves, which represents $48.9 \%$ of the total head loss.

In order to decrease the head loss in the system, it would be interesting to reduce the number of fittings that cause abrupt changes in water flow, especially by using direct-acting valves, but they have a relatively high cost compared with indirectacting hydraulic valves. In addition, the electrical power required for activation would be much higher.

\section{Minimization of cleaning water volume}

The results of cleaning water volume as a function of valve opening time are shown in Table 3. The lowest water volume for filter cleaning was $5.35 \mathrm{~L}(5.34=2.2(\mathrm{~F} 1)+1.69(\mathrm{~F} 2)+$ 1.46(F3)) resulting from the following combination: pulse1 $=250 \mathrm{~ms}$, pulse $2=1500 \mathrm{~ms}$ and pulse $3=250 \mathrm{~ms}$, for $\mathrm{F} 1$; pulse $1=250 \mathrm{~ms}$, pulse $2=1000 \mathrm{~ms}$ and pulse $3=250 \mathrm{~ms}$, for F2; and pulse $1=500 \mathrm{~ms}$, pulse $2=1000 \mathrm{~ms}$ and pulse $3=500$ $\mathrm{ms}$, for F3. The other combinations of number of pulses and valve opening time showed higher water volumes and caused problems in the closure of cleaning valves, due to the presence of solid particles. The particles retained in the cleaning valve were probably eliminated in the last pulse. Therefore, cleaning
Table 3. Volume of cleaning water for different combinations of valve opening time for the filters F1, F2 and F3

\begin{tabular}{|c|c|c|c|c|c|}
\hline \multicolumn{3}{|c|}{ Pulse time (ms) } & \multicolumn{3}{|c|}{ Filter } \\
\hline T1 & T2 & T3 & F1 & F2 & F3 \\
\hline \multirow{3}{*}{0} & 1000 & \multirow{3}{*}{500} & * & 1.97 & - \\
\hline & 1500 & & * & 2.3 & - \\
\hline & 2000 & & 2.99 & 2.88 & $*$ \\
\hline \multirow{4}{*}{250} & 500 & \multirow{4}{*}{250} & $\star$ & $\star$ & * \\
\hline & 750 & & * & $\star$ & $\star$ \\
\hline & 1000 & & * & $1.69 * \star$ & * \\
\hline & 1500 & & $2.20^{\star \star}$ & 2.25 & $1.50^{\star}$ \\
\hline \multirow{3}{*}{500} & 1000 & \multirow{3}{*}{500} & - & - & $1.46^{\star *}$ \\
\hline & 1500 & & $\star$ & - & 1.88 \\
\hline & 2000 & & - & - & 2.26 \\
\hline
\end{tabular}

the filters with three valve opening pulses was the most viable alternative.

When cleaning was performed using two pulses, only the filters F1 and F2 did not have leakage in the cleaning valves. However, the water volume was higher compared with the use of three pulses, even for the situation in which the total valve opening time was the same. This occurs because the times of pulses 1 and 3 are lower than the total time of opening of the valve $(0.75 \mathrm{~s})$, i.e., the valve is partially open, making the flow rate lower than the maximum flow rate of the valve, which occurs after complete opening. Thus, opening times longer than that for complete opening result in maximum flow rate of the valve and, consequently, in higher volume of cleaning water.

\section{Retention efficiency and volume of cleaning water per volume of filtered water}

Considering the efficiency of retention of total solids, only the factor concentration showed significant difference at 0.01 and 0.05 probability levels, and no interaction between the factors was significant (Table 4). Thus, the effect of the concentration of solids can be analysed collectively, with Er values of 71.7 and $78.3 \%$ for the concentrations of 500 and $1000 \mathrm{mg} \mathrm{L}^{-1}$, respectively (Table 5).

The treatment with highest concentration showed the highest efficiency of retention of solids, which can be related to the particle-size distribution, i.e., the frequency with which certain particle size is associated. The frequencies associated with the diameter of $50 \mu \mathrm{m}$ were 55.6 and $77.8 \%$, for the treatments with 500 and $1000 \mathrm{mg} \mathrm{L}^{-1}$, respectively, and these results corroborate those reported by Hatukai et al. (1997) and Puig-Bargués et al. (2005), who claimed that

Table 4. Result of the analysis of variance for the efficiency of retention of solids by the system

\begin{tabular}{|c|c|c|c|c|c|c|c|c|c|}
\hline \multirow{2}{*}{ Source of variation } & \multirow{2}{*}{ DF } & \multicolumn{4}{|c|}{ Total solids } & \multicolumn{4}{|c|}{ Solids with diameter larger than $50 \mu \mathrm{m}$} \\
\hline & & SS & MS & $F$ & $P(F>F c, \%)$ & SS & MS & $F$ & $P(F>F c, \%)$ \\
\hline Treatments & 7 & 0.052436 & 0.007491 & 4.198 & 0.832 & 0.0004758 & 0.0000680 & 1.380 & 27.938 \\
\hline C & 1 & 0.026243 & 0.026243 & 14.705 & 0.146 & 0.0000003 & 0.0000003 & 0.005 & 94.394 \\
\hline $\mathrm{F}$ & 1 & 0.007541 & 0.007541 & 4.225 & 5.652 & 0.0000033 & 0.0000033 & 0.066 & 79.992 \\
\hline $\mathrm{H}$ & 1 & 0.008162 & 0.008162 & 4.574 & 4.823 & 0.0002716 & 0.0002716 & 5.513 & 03.206 \\
\hline $\mathrm{C} \times \mathrm{T}$ & 1 & 0.002582 & 0.002582 & 1.447 & 24.653 & 0.0000039 & 0.0000039 & 0.079 & 78.280 \\
\hline $\mathrm{C} \times \mathrm{H}$ & 1 & 0.001555 & 0.001555 & 0.871 & 36.444 & 0.0000907 & 0.0000907 & 1.841 & 19.368 \\
\hline $\mathrm{T} \times \mathrm{H}$ & 1 & 0.000439 & 0.000439 & 0.246 & 62.657 & 0.0000794 & 0.0000794 & 1.611 & 22.247 \\
\hline $\mathrm{C} \times \mathrm{T} \times \mathrm{H}$ & 1 & 0.005914 & 0.005914 & 3.314 & 8.744 & 0.0000267 & 0.0000267 & 0.542 & 47.239 \\
\hline Residue & 16 & 0.028553 & 0.001785 & - & - & 0.0007882 & 0.0000493 & - & - \\
\hline Total & 23 & 0.080989 & - & - & - & 0.0012640 & - & - & - \\
\hline
\end{tabular}

$\mathrm{C}$ - Concentration of solids larger than $50 \mu \mathrm{m}$ (500 and $\left.1000 \mathrm{mg} \mathrm{L}^{-1}\right) ; \mathrm{F}$ - Frequency of flow reversal (11.11 and $22.22 \mathrm{mHz}$ ); $\mathrm{H}$ - Head loss increment for the cleaning of the filters (25 and $50 \%$; DF - Degrees of freedom; SS - Sum of squares; MS - Mean square 
Table 5. Filtration efficiency considering total solids and solids with diameter larger than $50 \mu \mathrm{m}$

\begin{tabular}{|c|c|c|c|c|c|}
\hline \multirow{4}{*}{$\begin{array}{c}\text { Reversal } \\
\text { frequency } \\
(\mathrm{mHz})\end{array}$} & \multirow{4}{*}{$\begin{array}{c}\text { Head } \\
\text { loss } \\
\text { increment } \\
(\%)\end{array}$} & Total & olids & \multicolumn{2}{|c|}{$\begin{array}{l}\text { Solids with diamete } \\
\text { larger than } 50 \mu \mathrm{m}\end{array}$} \\
\hline & & \multicolumn{4}{|c|}{ Concentration $\left(\mathrm{mg} \mathrm{L}^{-1}\right)$} \\
\hline & & 500 & 1000 & 500 & 1000 \\
\hline & & \multicolumn{4}{|c|}{ Er (\%) } \\
\hline \multirow{2}{*}{11.11} & 25 & 70.7 & 80.0 & 98.8 & 98.1 \\
\hline & 50 & 78.3 & 78.1 & 98.5 & 99.0 \\
\hline \multirow{2}{*}{22.22} & 25 & 67.4 & 74.6 & 98.1 & 98.0 \\
\hline & 50 & 70.4 & 80.6 & 98.9 & 99.2 \\
\hline \multicolumn{2}{|c|}{ Mean } & 71.7 & 78.3 & \multicolumn{2}{|c|}{98.6} \\
\hline \multicolumn{2}{|c|}{ Standard error } & 2.7 & 1.6 & \multicolumn{2}{|c|}{0.3} \\
\hline
\end{tabular}

the determination of particle-size distribution helps in the understanding of particle retention efficiency and can detect problems that would not be evidenced by other means. In the study developed by Puig-Bargués et al. (2005), the analysis of particle distribution before and after the filtration identified the occurrence of aggregation of solid particles after the filter. These authors expressed the retention efficiency as a function of filter diameter and observed efficiency values ranging from 30 to $100 \%$, which were dependent on the distribution of particles and the origin of the water.

In the present study, however, considering the retention efficiency for solids with diameter larger than $50 \mu \mathrm{m}$, no interaction with significant difference at 0.01 and 0.05 probability levels was observed (Table 4), with Ed $>50$ of $98.6 \pm 0.3 \%$. The significance level of the factor concentration was $94.39 \%$ for total solids, while for the filtration efficiency (Er) using solids with diameter larger than $50 \mu \mathrm{m}$, the factor concentration was equal to $0.146 \%$, proving that the increase in Er with the concentration of solids was influenced by the concentration of solids with diameter smaller than $50 \mu \mathrm{m}$.

The mean volume of water used for the cleanings in each performance test was $5.39 \mathrm{~L}$ per cleaning, which represented a cleaning water volume per filtered water volume of 8.0 and $12.6 \mathrm{~L} \mathrm{~m}^{-3}$, for the concentrations of 500 and $1000 \mathrm{mg} \mathrm{L}^{-1}$, respectively. This occurred because, for the water with lower concentration of solids $\left(500 \mathrm{mg} \mathrm{L}^{-1}\right)$, the evolution of head loss is slower and, in contrast, the number of backwashes per volume of filtered water is lower. According to Ribeiro et al. (2005), the variations in the quality of irrigation water influence the evolution of head loss in filtration systems, thus interfering with the intervals of backwashes, depending on the type of filter element. However, although the lowest concentration of solids in suspension $\left(500 \mathrm{mg} \mathrm{L}^{-1}\right)$ is half of the highest concentration (1000 $\mathrm{mg} \mathrm{L}^{-1}$ ), the mean water volume per cleaning did not follow the same proportion and represented $63.5 \%$ of the water volume for the highest concentration. According to Zeier \& Hills (1987), for lower concentrations, the amount of sand necessary to cause an increase in head loss is lower than that of the filtered volume and does not follow a linear relationship with the concentration. However, these authors emphasize that the volume of water per cleaning is, on average, the same.

Even for the use of water with high concentration of solids in suspension, the volumes of water required for filter cleaning can be considered as low, based on the limit of $10 \%$ of the filtered volume recommended by Tajrishy et al. (1994). These authors found backwash volume of $3 \%$ for sand filters with wastewater at concentration of $25 \mathrm{mg} \mathrm{L}^{-1}$, i.e., a concentration of solids 20 to 40 times less than that of the water used in the present study. Duran et al. (2009a,b) reported cleaning volumes of 27.7 and $3 \mathrm{~L} \mathrm{~m}^{-3}$, respectively, but for the concentration of solids in suspension of $10 \mathrm{mg} \mathrm{L}^{-1}$ from wastewater, i.e., a concentration of solids 100 times lower than that tested in the present study.

According to Qingsong et al. (2008), the amount of solids suspended in the irrigation water may reach concentrations higher than $1000 \mathrm{mg} \mathrm{L}^{-1}$, a value adopted as one of the treatment levels of the factor concentration in the evaluation of performance of the proposed system.

\section{Efficiency of backwash and flow reversal in filter cleaning (recovery of initial head loss)}

The profile of head loss as a function of filtration time, with the system operating in flow reversal (reversal time of 15 s) for the critical head loss variation of $35 \%$ and water with concentration of solids of $1000 \mathrm{mg} \mathrm{L}^{-1}$, is shown in Figure 4A.

According to Frizzone et al. (2012), an ideal filter is that in which the initial head loss is recovered after one backwash; in addition, it can be classified as effective or ineffective, based on the recovery of head loss (Duran-Ros et al., 2009b), which can be noticed in Figure 4A, through both the time between backwashes and the head loss after one backwash.

It is evident that time between backwashes decreases along the test, which indicates that the cleanings were not totally
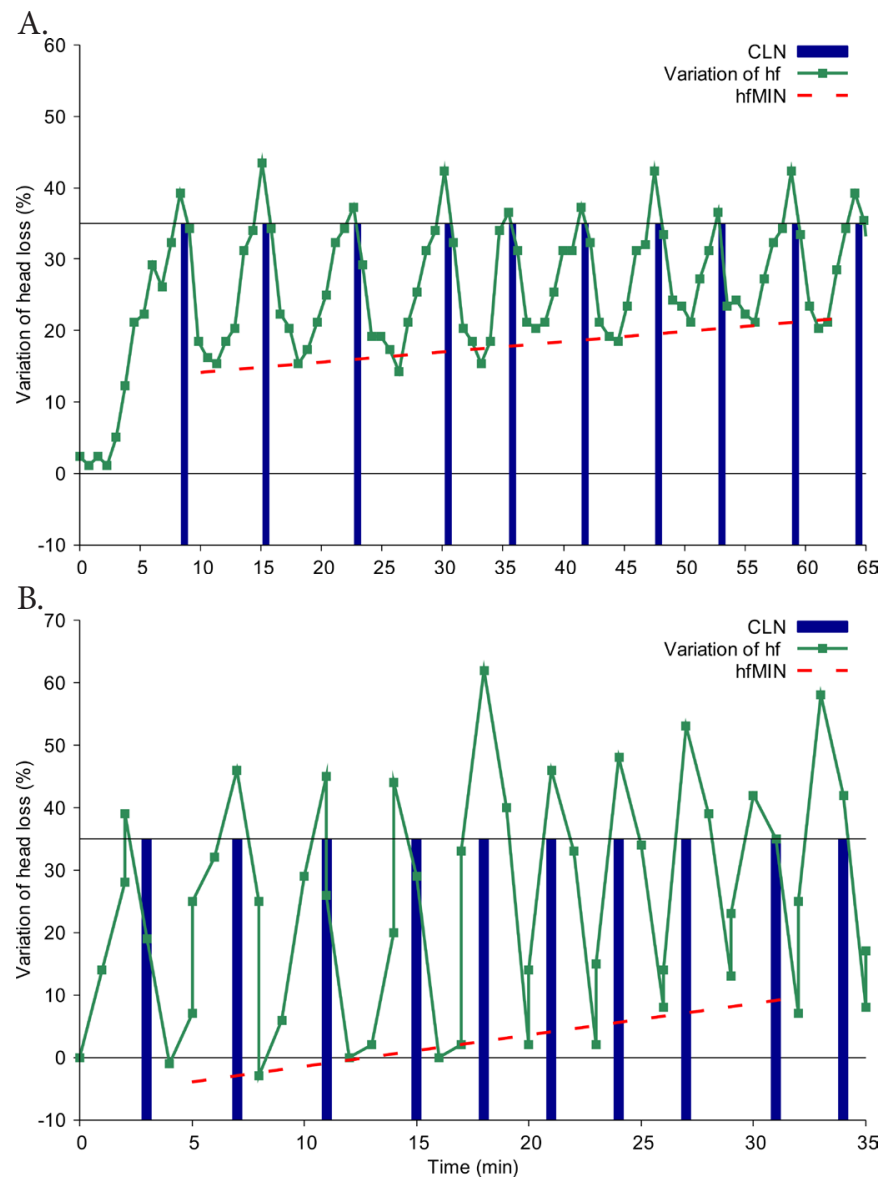

CLN - Cleaning; hfMIN - Minimum head loss after one backwash

Figure 4. Profile of head loss increment as a function of the number of backwashes of the filtration system: (A) with flow reversal; (B) without flow reversal 
effective. Additionally, for the system operating with flow reversal (Figure 4A), immediately after the first backwash, the head loss did not return to its initial value and tended to increase for the subsequent backwashes, as can be seen through the dashed line.

If this tendency continued, in $2.6 \mathrm{~h}$ the increment in head loss right after one cleaning would be equal to $35 \%$, i.e., cleanings had no effect on the head loss of the filters (saturation of the control).

Although the head loss returned to its initial value until the fourth cleaning, for the system operating without flow reversal, the head loss increment rate was superior (Figure $4 \mathrm{~B})$ and, if this rate continued, the saturation of the system would occur in $1.4 \mathrm{~h}$, a time shorter than that of the system with flow reversal. Furthermore, the numbers of backwashes per time of test were 9 and $17 \mathrm{~h}^{-1}$, for the filtration system with and without flow reversal, respectively. Therefore, it is supposed that flow reversal contributed to the removal of part of the particles retained on the screen, because the number of backwashes decreased.

The ineffectiveness of the cleanings in the recovery of the initial head loss is possibly associated with the solid particles retained on the filter screen, and its magnitude depends on particle diameter; smaller particles clog screen pores more easily in comparison to larger particles (Zeier \& Hills, 1987). Testezlaf \& Ramos (1995) comment that screen filters must be cleaned immediately after use, in order to prevent particles from becoming strongly aggregated, which compromises their removal.

When the screens were mechanically cleaned using a brush, the head loss returned to its initial value, indicating that the automatic cleanings were not effective at removing the particles retained on the screen. Thus, the proposed system will work with restrictions, requiring maintenance when the control system saturates. It should be pointed out that, when the concentration of total solids in the water is high, as in the analysed case, maintenance must be more frequent, which can make its use unviable.

\section{Conclusions}

1. The filtration system showed good efficiency at the retention of particles.

2. High-frequency flow reversal reduced the head loss evolution rate of the filtration system.

3. The logic of cleaning the filters using pulses promoted minimum volume of cleaning water.

4. The developed filtration system has potential for filtering low-quality irrigation water, but requires periodic maintenance, with manual cleaning of the filter element.

\section{ACKNowledgments}

To the São Paulo Research Foundation (FAPESP), for the financial support through the research project 2010/52457-6 and to the National Institute of Science and Technology in Irrigation Engineering (INCTEI), along with the Ministry of Science and Technology (MCT), the National Council for Scientific and Technological Development (CNPq) and the Coordination for the Improvement of Higher Education Personnel (Capes).

\section{Literature Cited}

Adin, A.; Alon, G. Mechanisms and process parameters of filter screens. Journal of Irrigation and Drainage Engineering, v.112, p.293-304, 1986. http://dx.doi.org/10.1061/(ASCE)0733-9437(1989)115:3(474)

Adin, A.; Elimelech, M. Particle filtration for wastewater irrigation. Journal of Irrigation and Drainage Engineering, v.115, p.474-487, 1989.

ASABE - American Society of Agricultural and Biological Engineers. ASAE S 539. Media filters for irrigation - Testing and performance. St. Joseph: ASABE, 2008. 7p.

Batista, R. O.; Souza, J. A. R.; Ferreira, D. C. Influência da aplicação de esgoto doméstico tratado no desempenho de um sistema de irrigação. Revista Ceres, v.57, p.18-22, 2010. http://dx.doi. org/10.1590/S0034-737X2010000100004

Camargo, A. P.; Molle, B.; Tomas, S.; Frizzone, J. A. An assessment of clogging effects on lateral hydraulics: proposing a monitoring and detection protocol. Irrigation Science, v.33, p.181-191, 2013.

Duran-Ros, M.; Puig-Bargués, M. J.; Arbat, G. Effect of filter, emitter and location on clogging when using effluents. Agricultural Water Management, v.96, p.67-79, 2009a. http://dx.doi.org/10.1016/j. agwat.2008.06.005

Duran-Ros, M.; Puig-Bargués, M. J.; Arbat, G.; Barragán, J. Cartagena, F. R. Performance and backwashing efficiency of disc and screen filters in microirrigation systems. Biosystems Engineering, v.103, p.3542, 2009b. http://dx.doi.org/10.1016/j.biosystemseng.2009.01.017

Frizzone, J. A.; Freitas, P. S. L.; Rezende, R.; Faria, M. A. Microirrigação: Gotejamento e microaspersão. 1.ed. Maringá: Eduem, 2012.356p.

Hatukai, S.; Ben-Tzur, Y.; Rebhun, M. Particle counts and size distribution in system design for removal of turbidity by granular deep bed filtration. Water Science Technology, v.36, p.225-230, 1997. http://dx.doi.org/10.1016/S0273-1223(97)00453-8

Lemos Filho, A. F.; Zanini, J. R.; Silva, E. R. S.; Cazetta, J. O.; Ferraudo, A. S. Sistema com aeração, decantação e filtragem para a melhoria da qualidade de água em irrigação localizada. Engenharia Agrícola, v.31, p.506-519, 2011. http://dx.doi.org/10.1590/S010069162011000300011

Nakayama, F. S.; Bucks, D. A. Emitter clogging effects on trickle irrigation uniformity. Transactions of the ASAE, v.24, p.77-80, 1981. http://dx.doi.org/10.13031/2013.34203

Oliveira, C. F.; Frizzone, J. A.; Rettore Neto, O. Recomendação de equações para determinação da perda de carga em filtros de tela. Revista Brasileira de Agricultura Irrigada, v.1, p.3-8, 2007. http:// dx.doi.org/10.7127/rbai.v1n100005

Pinto, M. F. Desenvolvimento e avaliação de um sistema de filtragem com reversão de fluxo de alta frequência. Piracicaba: ESALQ/USP, 2013. 99p. Tese Doutorado. http://dx.doi.org/10.11606/t.11.2013. tde-12072013-082758

Pinto, M. F.; Camargo, A. P.; Almeida, Alves, D. G.; Botrel, T. A. Desenvolvimento de um sistema para controle do $\mathrm{pH}$ da água para microirrigação. Revista Brasileira de Engenharia Agrícola e Ambiental, v.15, p.211-217, 2011. http://dx.doi.org/10.1590/ S1415-43662011000200015

Puig-Bargués, J.; Arbat, G.; Barragán, J.; Cartagena, F. R. Effluent particle removal by microirrigation system filters. Spanish Journal of Agricultural Research, v.3, p.182-191, 2005. http://dx.doi. org/10.5424/sjar/2005032-139 
Qingsong, W.; Gang, L.; Jie, L.; Yusheng, S.; Wenchu, D.; Shuhuai, H. Evaluations of emitter clogging in drip irrigation by two-phase flow simulations and laboratory experiments. Computers and Electronics in Agriculture, v.63, p.294-303, 2008. http://dx.doi. org/10.1016/j.compag.2008.03.008

Ribeiro, T. A. P.; Paterniani, J. E. S.; Colleti, C. Chemical treatment to unclogg dripper irrigation systems due to biological problems. Scientia Agricola, v.65, p.1-9, 2008. http://dx.doi.org/10.1590/ S0103-90162008000100001

Ribeiro, T. A. P.; Paterniani, J. E. S.; Silva, M. J. M.; Airoldi, R. P. S. Efeito da qualidade da água na perda de carga em filtros utilizados na irrigação localizada. Revista Brasileira de Engenharia Agrícola e Ambiental, v.9, p.1-6, 2005. http://dx.doi.org/10.1590/S1415-43662005000100001
Tajrishy, M. A.; Hills D. J.; Tchobanoglous, G. Pretreatment of secondary effluent for drip irrigation. Journal of Irrigation and Drainage, v.120, p.716-731, 1994.

Testezlaf, R. Filtros de areia aplicados à irrigação localizada: teoria e prática. Engenharia Agrícola, v.28, p.604-613, 2008. http://dx.doi. org/10.1590/S0100-69162008000300020

Testezlaf, R.; Ramos, J. P. S. Sistema automatizado para determinação de perda de carga em filtros de tela e disco usados na irrigação localizada. Pesquisa Agropecuária Brasileira, v.30, p.1079-1088, 1995.

Zeier, K. R.; Hills, D. J. Trickle irrigation screen filter performance as affected by sand size and concentration. Transaction of the ASAE, v.30, p.735-739, 1987. http://dx.doi.org/10.13031/2013.30468 